\title{
A Rare Cause of Acute Abdomen: Duodenal Perforation of Gastrointestinal Stromal Tumors
}

\section{Nadir Bir Akut Batın Nedeni: Duodenal Gastrointestinal Stromal Tümör Perforasyonu}

\author{
Yasemin Cihan ${ }^{1}$, Talha Sarigöz ${ }^{2}$, Tamer $\operatorname{Ertan}^{2}$, Ömer Topuz ${ }^{2}$, Yusuf Sevim² \\ ${ }^{1}$ Kayseri Eğitim Ve Araştırma Hastanesi, Radyasyon Onkoloji Bölümü, Türkiye \\ ${ }^{2}$ Kayseri Eğitim Ve Araştırma Hastanesi, Genel Cerrahi Anabilim Dalı, Türkiye
}

Dergiye Ulaşma Tarihi: 19.9.2015 Dergiye Kabul Tarihi: 24.8.2016 Doi: 10.5505/aot.2016.03511

Dear Editor,

Gastrointestinal stromal tumors (GIST) are the most common mesenchymal tumors of the gastrointestinal tract (1). They grow from the interstitial cells of Cajal which are located in the submucosal and myentric plexus (2). They may occur from lower esophagus to anus but a great majority $(50-70 \%)$ is seen in the stomach followed by small intestines (33\%). Duodenal origin makes $6-21 \%$ of small intestinal GIST and mostly second portion is involved $(3,4)$. In this letter, we want to evaluate diagnosis and surgical treatment of duodenal GIST in emergency setting by presenting a rare case.

A 42 year-old male patient admitted to emergency department with history of acute abdominal pain of one day's duration. On abdominal examination, it was tender generally and right upper quadrant rebound tenderness was present.

Computed tomography scan with intravenous contrast was performed. In the axial tomography images, there were a hypodense $9 \times 5 \mathrm{~cm}$ tumoral mass with intratumoral gas and fluid densities, perihepatic free gas, heterogeneous increase in mesenteric fat, mesenteric lymph nodes and pelvic free fluid. After the initial investigation, diagnosis of duodenal mass perforation was made and patient went to urgent surgery.

Surgery consisted of diagnostic laparotomy and it revealed perforated hemoragic 10x8 cm mass originated from the second portion of the duedonum. Whipple procedure was performed.

On literature review, most data on duodenal GIST are either from single case reports or from a few small series and most of them treated with elective surgery. But also 
they may require urgent intervention. Although they are usually asymptomatic, while the tumor enlarges, it causes variable symptomatology like gastrointestinal bleeding which may be chronic and mild or sudden and massive (5). The next most common presentations are abdominal discomfort, pain and swelling. Gastroscopy is a useful procedure for duodenal GIST diagnosis. During upper gastrointestinal endoscopy if the tumor is smaller than $2 \mathrm{~cm}$ and heavily accompanied with blood clots, it is difficult to dissociate hemobilia, ampulla or duodenal ulcer from GIST (6). For these reasons, a complete examination should be conducted during upper gastrointestinal bleeding to prevent misdiagnosis.

\section{References}

1. Joensuu H, Fletcher C, Dimitrijevic S, Silberman S, Roberts P, Demetri G. Management of malignant gastrointestinal stromal tumours. Lancet Oncol. 2002 30;3:655-64

2. Miettinen M, Lasota J. Gastrointestinal stromal tumors-definition, clinical, histological, immunohistochemical, and molecular genetic features and differential diagnosis. Virchows Archiv. 2001;438:1-2

3. DeMatteo RP, Lewis JJ, Leung D, Mudan SS, Woodruff JM, Brennan MF. Two hundred gastrointestinal stromal tumors: recurrence patterns and prognostic factors for survival. Ann Surg. 2000;231:51

4. Winfield RD, Hochwald SN, Vogel SB, Hemming AW, Liu C, Cance WG, et al. Presentation and management of gastrointestinal stromal tumors of the duodenum. Am Surg. 2006;72:719-23
Either elective or urgent, the treatment of choice for duodenal GIST is complete surgical excision. This can be performed by local or segmental duodenal resection with preservation of the pancreas for small tumors. For big tumors, a pancreaticoduodenectomy (Whipple procedure) is required (7). No lymph node dissection is required since they are very unlikely to be involved (8). Yet, the optimal surgical treatment for duodenal GIST has never been fully assessed. With the implementation of tyrosine kinase inhibitors as an adjuvant therapy, better quality of life and overall-survival have been reported (9).

\section{Conflict of interest: None}

5. Roberts PJ, Eisenberg B. Clinical presentation of gastrointestinal stromal tumors and treatment of operable disease. Eur J Cancer, 2002;38:Supp15:pS37-8

6. Lin C, Chang Y, Zhang Y, Zuo Y, Ren S. Small duodenal gastrointestinal stromal tumor presenting with acute bleeding misdiagnosed as hemobilia: Two case reports. Oncol Lett. 2012;4:1069-71

7. Chung JC, Kim HC, Hur SM. Limited resections for duodenal gastrointestinal stromal tumors and their oncologic outcomes. Surgery today. 2015;10:1-7

8. Connolly EM, Gaffney E, Reynolds JV. Gastrointestinal stromal tumours. Br J Surg, 2003; 90:1178-86

9. DeMatteo RP, Ballman KV, Antonescu CR, Maki RG, Pisters PW, Demetri GD, et al. Adjuvant imatinib mesylate after resection of localised, primary gastrointestinal stromal tumour: a randomised, double-blind, placebo-controlled trial. Lancet. 2009;373:1097-104 